\title{
Equilibrium Real Exchange Rate and Misalignment: The Sierra Leone Perspective
}

\author{
Abu Bakarr TARAWALIE ${ }^{1}$ \\ ${ }^{1}$ Lecturer at the Department of Economics and Commerce, Fourah Bay College, University of Sierra Leone, SIERRA \\ LEONE
}

Correspondence: Abu Bakarr TARAWALIE, E-mail: tarawalieabu@yahoo.com

Received: May 25, 2021

doi:10.11114/aef.v8i3.5267
Accepted: June 10, $2021 \quad$ Available online: June 17, 2021

URL: https://doi.org/10.11114/aef.v8i3.5267

\begin{abstract}
This paper estimates the equilibrium real effective exchange rate and determine the level of exchange rate misalignment in Sierra Leone, for the period 1980 to 2018. The paper utilizes the behavioral equilibrium exchange rate methodology within the Johansen maximum likelihood framework to estimate the long run equilibrium real effective exchange rate. The unit root test result shows that all the variables are integrated of order one, whilst the cointegration test establishes the existence of one cointegrating vector as evidenced by both the Trace and Maximum Eigen Statistics. The normalized long run results reveal that openness, government expenditure and money supply were the most significant determinants of the real effective exchange rate in the long run. Furthermore, the findings reveal that the real effective exchange rate experienced sustained deviation from the long run equilibrium real effective exchange rate during the study period, with episodes of overvaluation and undervaluation. Specifically, the real effective exchange rate was overvalued by 3.69 percent during the period between 1980-1985; undervalued by 1.8 percent between 1986-1997, and overvalued by 0.9 percent between 1998-2004, Thus, the paper reveals episodes of misalignment of the real effective exchange rate. Based on these findings, the study recommends that, the monetary authorities should ensure stability of the exchange rate and maintain price stability, through sterilization of capital flows as well as contain money growth within the statutory limit.
\end{abstract}

Keywords: exchange rate misalignment, behavioral equilibrium exchange rate, Sierra Leone, annual series

\section{JEL Classification Numbers: F31, F41, M41}

\section{Introduction}

In the past few decades, the issue of real exchange rate (RER) management has attracted considerable attention from policy makers and researchers. The RER is considered a key macroeconomic relative price in international economics, used as a measure of international competitiveness for a country. It also guides resource allocation in production and spending behavior, hence directly affecting a country's welfare and standards of living. A significant challenge in the literature consists of determining an exchange rate that simultaneously achieves external and internal equilibrium. The equilibrium real effective exchange rate (EREER) is the exchange rate which simultaneously achieve internal and external equilibrium. Internal balance is achieved when the market for non-tradeable goods clears in the present and is expected to clear in the future, while external equilibrium holds when present and future current account balances are compatible with long-run sustainable capital flows. The EREER is a variable that is mainly influenced by key macroeconomic fundamentals. The RER is said to be misaligned, when it departs from the fundamental RER that would have prevailed in the absence of price rigidities and other short run factors. Hence, misalignment of the real exchange rate is a gap between actual and equilibrium real exchange rate.

The literature posits that stability of the RER is a significant factor in improving the external sector of a given economy and the overall economic performance. An exchange rate is deemed overvalued or undervalued if it appreciates or depreciates in relation to its equilibrium level. Both conditions are described as misalignment of the exchange rate. An overvalued exchange rate will create foreign currency shortage, affect the competitiveness of a country, exacerbate the current account deficit, and dampen the growth potential of a country. Conversely, an undervalued exchange rate will increase the cost of imported goods, create inflationary pressure, cause misallocation of resources, affect investment and aggregate demand and negatively impact on economic growth (Bahmani-Oskooee and Miteza, 2003). The theoretical literature has identified three approaches in the determination of EREER; the purchasing power parity (PPP), the fundamental and the behavioral 
approaches. The PPP approach posits that the exchange rate adjusts to equate relative price differential between the home country and a foreign country. The fundamental equilibrium exchange rate on the other hand, is an exchange rate that is consistent with both internal and external equilibrium. Internal balance is reached when the economy is at full employment output and operating in a low inflation environment. External balance refers to a sustained balance of payments position over the medium or long term. The behavioral real effective exchange rate (BEER) explains the behavior of the exchange rate in the medium and long run, which is derived based on macroeconomic fundamentals.

Sierra Leone is a member of the West African Monetary Zone (WAMZ), a body that is aspiring to form a monetary union with a single currency- Eco and a common central bank- the West Africa Central Bank. One of the convergence criteria is that, member states are required to maintain exchange rate stability- the exchange rate should fluctuate within the margin of \pm 15 percent of the WAMZ Exchange rate Mechanism (ERM-II). Achieving this criterion remains a daunting challenge for Sierra Leone, given the persistent depreciation of the domestic currency, coupled with high level of imports and lower exports. Thus, the effective management of the exchange rate remains a useful indicator that will gauge the external performance and the overall international competitiveness of the country. Sierra Leone's exchange rate system has evolved through six exchange rate regimes. The first regime which spanned the period 1964 to 1978, witnessed a pegged system between the leone and the British pound at Le 2 to $£ 1$. During this period, the leone was relatively stable albeit it devalued by 14.7 percent in 1967, on account of the devaluation of the pound. The second regime was operationalized in November 1978, when the leone was delinked from the pound and pegged to the Special Drawing Rights (SDR) of the IMF at a rate of Le 1 to 0.7316 SDR, given that the SDR was less susceptible to external shock than the pound. The third exchange rate regime witnessed the implementation of the dual exchange rate (two-tier) in 1982, a system which allows an official rate for government transaction and a commercial rate for other transactions.

The fourth regime was introduced in 1983, when the leone was pegged to the US Dollar at a rate of Le 2.50 to $\$ 1$. The fifth regime was implemented in 1986 with the introduction of a floating exchange rate system, bringing the rate at Le 53 to $\$ 1$. It was later revalued at a rate of Le 23 to $\$ 1$ in 1987, so as to curb inflationary pressure. The sixth regime was introduced in 1990 with a full liberalization of the exchange rate and the establishment of exchange rate bureaus, with a view to ensure broad macroeconomic stability and promote private sector participation. Figure 1 presents trend in REER movement. The country witnessed significant depreciation between the period 1981-1984, due partly to adverse external sector development exacerbated by inappropriate macroeconomic and fiscal management policies, especially during the hosting of the Organization of the African Union (OAU) Summit in 1980, that led to huge expenditure outlay and increased demand for tradeable goods and services. The country however, witness REER appreciation between 1985 to 1987, corresponding to the introduction of the floating exchange rate and the Structural Adjustment Programme. However, the REER albeit depreciating, remained relatively low and stable since 1990, with slight appreciation between 2002 to 2004, due partly to the signing of the Lomé Peace Accord, which marked the end of the civil conflict and ushered in a new dawn of political and economic stability, increased foreign exchange inflows and boost foreign direct investment.

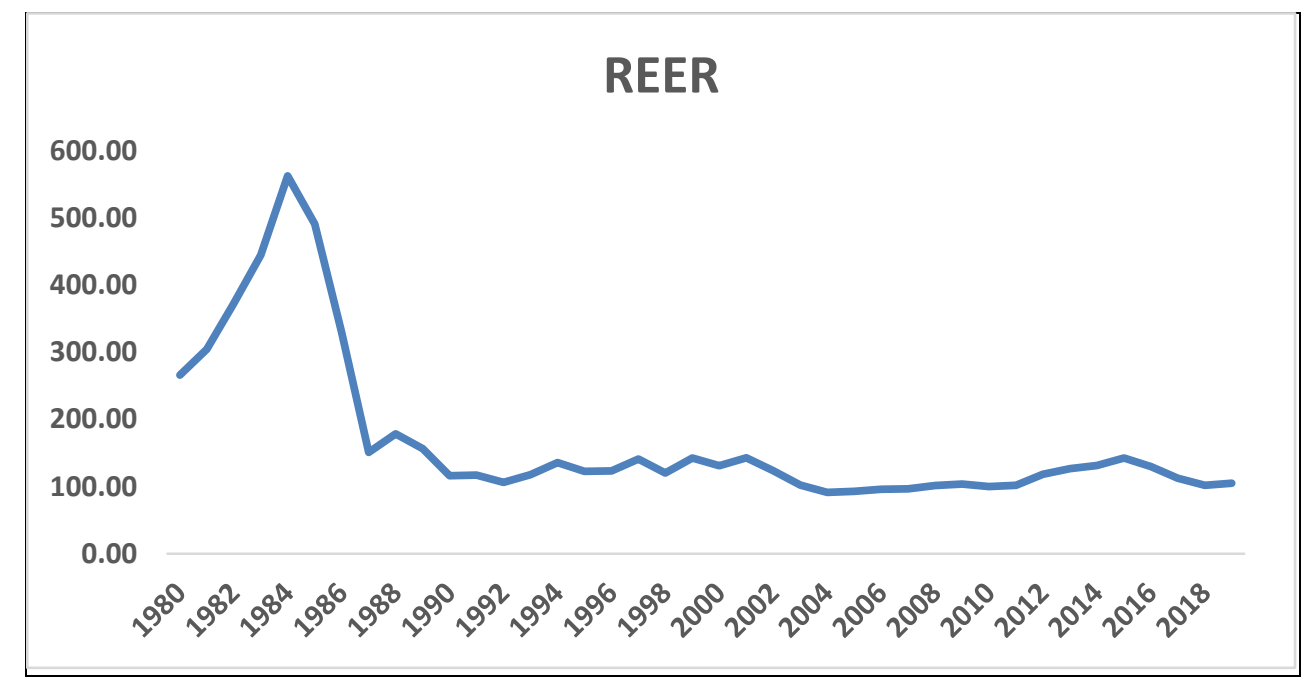

Figure 1. Trend in Real Effective Exchange rate

Source: Author's compilation 
Thus, the paramount question for policy makers is whether the REER is overvalued or undervalued in relation to sustainable equilibrium levels. This paper seeks to provide answer to this question. The aim of this paper is to estimate the equilibrium real effective exchange rate and determine the level of exchange rate misalignment in Sierra Leone using the BEER framework and the Johansen maximum likelihood procedure, covering the period 1980 to 2018 . The choice of the BEER approach is due to its potential to capture all the fundamental movements of the exchange rates. Also, the BEER is a highly tractable method used to gauge an equilibrium exchange rate, especially when using single time series equation. It also produces exchange rate misalignment values that are free from normative elements. Given that the REER serves as a strong indicator of a country's external competitiveness, this study provides a solid foundation for policy makers to fully understand and appreciate the dynamics of equilibrium exchange rate and the macroeconomic fundamentals that cause misalignment in the exchange rate. The study provides an indication as to whether the REER is overvalued or undervalued, which will guide policy makers in the design of prudent policies aimed at maintaining a sustainable REER, consistent with its equilibrium trajectory. Finally, the author observed that, despite the abundant literature on real exchange rate mislaignmnet, there is no country specific study on Sierra Leone. Most of the studies conducted on Sierra Leone are based on panel data analysis. Thus, this study remains one of the first country specific study on Sierra Leone that seeks to estimate the equilibrium exchange rate and establish the degree of misalignment. Following this introduction, the rest of the paper is structured as follows: Section II discusses the empirical literature on EREER and exchange rate misalignments. Section III presents the methodology, whilst section IV focuses on the empirical results and discussion on key findings. Section V concludes the paper with policy recommendations.

\section{Empirical Review}

This section presents a summary of the empirical studies on EREER and misalignment. Gachoki et al (2019) investigated the determinants of RER and its misalignment in Kenya, using quarterly data spanning 2000 to 2016. The study employed the BEER. The finding revealed that macroeconomic fundamentals are the main drivers of RER. The study also showed that the exchange rate was overvalued by 5.9 percent and undervalued up to 5.2 percent. In a related study, Kiptui and Ndirangu, (2015) investigated the RER misalignment in Kenya utilizing quarterly series from 2000 to 2014 and employing the VECM approach. The result confirmed that the EREER approximate its long run equilibrium level. Also, Moore et al (2004) employed the VECM to estimate the EREER for Barbados, Jamaica, and Trinidad and Tobago spanning 1970 to 2001. The findings revealed incidence of overvalued exchange rate for Barbados and Jamaica, and an undervalued exchange rate for Trinidad and Tobago. Lugaiyamu, (2015) investigated the relationship between real exchange rate and its fundamental determinants in Tanzania using data spanning 1987 to 2012 and the Granger-causality test. The study found no long run relationship between RER and its fundamental. Elbadawi and Soto (1994), investigate the RER in Chile from 1960 to1992. The study found that RER was largely driven by its fundamentals. Jayaraman and Choong (2011) estimated the long-run equilibrium real exchange rate and examining the short-run dynamics of real exchange rates and detection of possible misalignment in Fuji for the period 1980 to 2007. The study utilizes the Johansen technical and the empirical finding showed that that there has been no large, persistent instance of misalignment of Fiji's Real Effective Exchange Rate.

Using the BEER approach and data from 1960 to 2013, Ibrahim, (2014) examined the effects of RER misalignment on imports and exports in Nigeria. The finding revealed that the REER was overvalued between 1960 and 1985, and undervalued between 1986 and 2013. Juthathip, (2009) employed similar methodology to examined the ERER and misalignment in developing Asian countries, using quarterly series from 1995 to 2008 . The findings showed that the RER was overvalued during 1997-98. Iimi (2006) also employed the BEER approach to analyze the behaviour of the RER in Botswana spanning 1985 to 2004. The result confirmed that, the pula was undervalued in the late 1980s but overvalued thereafter within the study period. Using single equation for the period 1987 to 1993, Baffes et al (1999) examined the level of misalignment for Côte d'Ivoire and Burkina Faso. The finding showed that, RER was overvalued by 34 percent for Côte d'Ivoire. Hyder and Mahbood (2006) estimated the ERER and misalignment for Pakistan from 1978 to 2005 . They utilized the Engel Granger approach. The result showed that the volatility in real effective exchange rate tend to be smaller. Zhang (2002) estimated the ERER in Hong Kong with quarterly data from1984 to 1988. The results showed the exchange rate was overvalued between 1993Qy3-1995Q2.but adjusted back to equilibrium beyond 1995Q2. In their study on Argentina, Alberola et al. (2004) utilized cointegration approach to estimate the EREER for Argentina for the period 1960 to 2001. The study found significant level of misalignment of the peso. Daboh (2010) investigated the determinants of Equilibrium real exchange rate in the West African Monetary Zone (WAMZ), using the BEER. Employing annual data from 1970 to 2006, the result confirmed that RER were found to be misaligned for all the countries of the WAMZ. The speed of adjustment of the RER to equilibrium ranges from one year in the Gambia to four years in Nigeria. It is evident from the review of previous studies that, the empirical literature has produced conflicting findings. As such, a study of this nature is relevant for the Sierra Leone economy. 


\section{Methodology}

\subsection{Model Specification}

This paper employs the BEER methodology within the framework of the Johansen approach to estimate the EREER in Sierra Leone and measure the degree of misalignment. The BEER approach is based on establishing the behavioural relationship between real exchange rate and the key fundamentals. The approach consists of three steps. First, cointegration econometric techniques are used to estimate a long-run relationship between the real exchange rate and a set of fundamentals. Second, the equilibrium real effective exchange rate is computed as a function of the values of the fundamentals at a particular point in time. This can be achieved by decomposing the series into permanent and transitory components using either the Hodrick-Prescott (HP) filter or a Beveridge-Nelson decomposition. Finally, exchange rate misalignment is derived directly as the difference between the actual real effective exchange rate and the equilibrium real effective exchange rate. Thus, the BEER approach focuses on identifying the main long run drivers of the real effective exchange rate, and obtaining the equilibrium real effective exchange rate.

Following the empirical work of Petrevski (2007), the study proceeds to specify the long run REER model. The model specification utilized in this study is presented as follows:

$$
\text { reer }=f(T T, O P, G E, M S, C F)
$$

For estimation purposes, Equation 1 can be re-specified as follows:

$$
\text { Ln reer }=\alpha_{0}+\alpha_{1} \log T T+\alpha_{2} \log O P+\alpha_{3} \log G E+\alpha_{4} \log M S+\alpha_{5} f \log C f+\mu_{t}
$$

Where, reer is real effective exchange rate; TT is terms of trade, defined as the ratio of export price index to import price index; OP is openness, which measures the degree of openness of the Sierra Leone economy to international trade, defined as the ratio of the sum of export and import to GDP; GE is government expenditure, measured as the ratio of total government expenditure to GDP; MS is money supply represented as broad money as a percent of GDP; and CF is Net Capital Flows expressed as a percentage of GDP, which capture the effect of external resource balances on equilibrium, $\alpha_{i}(\mathrm{i}=1, \ldots \ldots, 5)$ are long run coefficients and $\mu_{i}$ is the error term.

The theoretical literature suggests that, the coefficient of TT cannot be determined a priori, but depends on the income and substitution effect. If the income effect dominates, then the REER will experience an appreciation, but REER depreciation will occur if the substitution effect dominates. Furthermore, the coefficient of openness cannot be determined apriori. An increase in trade openness depreciates REER, whilst a decline in trade openness will appreciate the REER.

The theory suggests that, the impact of government expenditure on the REER depends on the composition of government expenditure. An increase in government expenditure on non-tradeable goods and services, will increase prices of non-tradable goods resulting to an appreciation of the REER. Conversely, an increase in government expenditure on tradeable goods (due to expenditure switching in favour of tradeable goods), will lead to a fall in price of non-tradeable goods resulting to a depreciation. An increase in money supply will increase domestic prices, resulting to an appreciation of the REER. Finally, an increase in net capital inflow will lead to an appreciation of the REER.

\subsection{Estimation Technique}

This study utilizes the Johansen Maximum Likelihood estimation technique to investigate the existence of long run cointegrating relationship between REER and its fundamentals. The first step in the Johansen framework is to conduct a stationarity test to identify the level of integration of the variables. Once the stationarity of the variables is established, we proceed with the Johansen test to verify the existence of cointegration. We estimate a VAR model with the appropriate lag length to establish the existence of cointegration using both the Trace statistics and maximum Eigen Values. The model is also used to estimate the long run relationship between REER and its fundamental determinants as given in Equation 2. The long run estimates of Equation 2 are obtained by normalizing the coefficients of the significant variables of the fundamentals. This is done by reversing the signs of the coefficients of the fundamentals obtained from the Johansen results in order to establish the long run results. Once the long run relationship is established between the REER and its fundamental, we then proceed to estimate the equilibrium real effective exchange rate (EREER).

Note that, results of the long run REER obtained from the normalized Equation 2, will enable us to calculate the EREER by imposing restrictions on the long run coefficients of the fundamentals to obtain the permanent values. Thus, permanent values for the fundamentals are computed using the Hodrick-Prescott (1980) filter methodology. This methodology filters 
out the transitory components of the fundamental series. The permanent components for each series, i.e., the sustainable values of the fundamentals, are obtained and each of these variables is multiplied by the corresponding coefficients of the fundamentals derived from the long run normalized variables, to obtain the EREER. This approach smooths out any temporary components in the fundamentals.

Following the determination of the EREER, we proceed to compute the real effective exchange rate misalignment, which is the sustained deviation of the actual REER from the EREER as the second step. Misalignment is calculated as follows:

$$
\text { Misalignment }=\frac{(\text { REER-EREER })}{E R E E R} * 100
$$

\subsection{Data Sources}

The study uses annual time series data covering the period 1980-2018. The choice of the time period is premised on the foundation that, it combines the various exchange rate regimes to give a clear picture on the operationalization of the exchange rate during this period. The time frame is also due to the availability of data. All variables are expressed in natural logarithms. Variables were obtained from the World Development Indicator and the International Financial Statistics (IFS) of the IMF.

\section{Empirical Results}

\subsection{Descriptive Statistics}

The study establishes the univariate statistics of the variables to assess their statistical properties. The results of the descriptive statistics are presented in Table 1. Critical analysis of Table 1 reveals the mean and skewness of all the variables are less than one (albeit some with high values), which denotes most of the variables have standard normal distribution. This is based on the rule of thumb which indicates that, for any standardized normal variable $Z_{t}$, the mean value and skewness should be closer to zero. Also, Terms of trade and capital flows are positively skewed, while all other variables are negatively skewed. Juxtaposed against this are the probability values and the Jarque-Bera test of normality, which shows that the residuals are normally distributed, due to low probability values.

Table 1. Results of Univariate Statistics

\begin{tabular}{|l|r|r|r|r|r|r|r|}
\hline & \multicolumn{1}{|l|}{ Mean } & \multicolumn{1}{l|}{ Median } & \multicolumn{1}{l|}{ Std. Dev. } & \multicolumn{1}{l|}{ Skewness } & \multicolumn{1}{l|}{ Kurtosis } & Jarque-Bera & \multicolumn{1}{l|}{ Prob } \\
\hline REER & 0.61 & 0.45 & 0.54 & -0.71 & 5.89 & 0.00 \\
\hline TT & 0.26 & 0.16 & 0.34 & 0.62 & 5.24 & 21.2 & 0.03 \\
\hline OP & 0.41 & 0.39 & 0.18 & -0.48 & 2.87 & 0.09 \\
\hline MS & 0.05 & 0.09 & 0.19 & -0.56 & 5.14 & 12.3 & 0.6 \\
\hline CF & 0.02 & 0.07 & 0.46 & 0.63 & 3.94 & 0.05 \\
\hline GE & 0.27 & 0.35 & 0.22 & -0.71 & 3.51 & 0.03 \\
\hline
\end{tabular}

\subsection{Unit Root Tests}

The study performs the unit root test on all the variables to determine their order of integration using both the Augmented Dickey Fuller (ADF) and Phillip- Perron (PP) unit root tests. The results as presented in Table 2, reveals all variables are non-stationary in levels but became stationary after the first difference, hence they are characterized by I(1) series.

Table 2. Results of Unit Root Tests

\begin{tabular}{|l|l|l|l|l|l|}
\hline Variables & \multicolumn{4}{l|}{ Augmented Dickey-Fuller } & \multicolumn{2}{l|}{ Phillips Perron } & Order of integration \\
\hline & Level & $1^{\text {st }}$ difference & Level & $1^{\text {st }}$ difference & \\
\hline REER & -2.146 & $-3.8212^{* *}$ & -1.982 & $-3.752^{* *}$ & $\mathrm{I}(1)$ \\
\hline TT & -1.973 & $-5.180^{*}$ & -2.171 & $-5.016^{*}$ & $\mathrm{I}(1)$ \\
\hline OP & -2.302 & $-4.101^{* *}$ & -1.932 & $-4.432^{*}$ & $\mathrm{I}(1)$ \\
\hline CF & -2.013 & $-6.062^{*}$ & -2.210 & $-5.453^{*}$ & $\mathrm{I}(1)$ \\
\hline MS & -2.218 & $-4.732^{*}$ & -2.011 & $-4.821^{*}$ & $\mathrm{I}(1)$ \\
\hline GE & -2.124 & $-4.543^{*}$ & -2.114 & $-4.533^{*}$ & $\mathrm{I}(1)$ \\
\hline Notes: $*$ and $* *$ indicate significance at $1 \%$ and 5\% levels, respectively. \\
\hline
\end{tabular}




\subsection{Cointegration Tests}

The study conducts test of cointegration using the Johansen maximum likelihood technique. To implement the Johansen cointegration analysis, the study estimated a VAR model with variables in levels. A pre-condition for the estimation of the VAR model is to establish the optimal number of lags to be included in the cointegration analysis. Thus, an optimal lag length of two was chosen based on the Akaike information criterion (AIC), the Schwarz criterion (SC) and Hanna-Quinn information criterion (HQ). The results of the cointegration tests are reported in Table 3. Both the Trace and Maximum-eigen tests indicate one cointegrating vector at the $95 \%$ critical level. Table 4 present the results of the long run normalized results.

Table 3. Results of Cointegration tests

\begin{tabular}{|l|l|l|l|l|}
\hline & \multicolumn{1}{|c|}{ Maximum Eigen Statistics } & \multicolumn{2}{c|}{ Trace Statistics } \\
\hline Hypothesis & Test Statistics & $95 \%$ & Test Statistics & $95 \%$ \\
\hline $\mathrm{P}=0$ & 33.63 & 30.04 & 120.62 & 82.5 \\
\hline $\mathrm{P} \leq 1$ & 11.92 & 28.8 & 58.37 & 59.5 \\
\hline $\mathrm{P} \leq 2$ & 9.52 & 17.9 & 24.74 & 39.9 \\
\hline $\mathrm{P} \leq 3$ & 9.23 & 20.21 & 22.03 \\
\hline
\end{tabular}

Table 4. Normalized Cointegration Results

\begin{tabular}{|l|l|l|l|l|}
\hline REER & OP & GE & MS & Intercept \\
\hline Coefficients & 0.142 & 0.204 & -0.084 & 5.642 \\
\hline t-statistics & $2.723 * *$ & $3.201 * *$ & $2.622 * *$ & $4.021 *$ \\
\hline Notes: * and **indicate significance at 1\% and 5\% levels, respectively \\
\hline
\end{tabular}

Given the result from the cointegrating vector, we obtain the normalized long run real effective exchange rate relationship as follows:

$$
L R E E R=5.642+0.14 L O P+0.20 L G E-0.08 L M S
$$

$$
[4.02] \quad[2.72] \quad[3.20] \quad[2.62]
$$

Note: Values in [ ] represent t-statistics.

The normalized long run results as shown in equation (4) reveals government expenditure, openness and money supply are the determinants of the long run REER in Sierra Leone during the study period. Specifically, the result posits that government expenditure has a positive impact on REER in the long run with statistically significant coefficient. An increase in government expenditure will increase the demand for tradeable goods, which causes expenditure switching away from non-tradeable goods, which will correspondingly decrease prices of non-tradeable goods. Hence resulting to a depreciation of the REER. This result bodes well with the findings of Abbes (2014), Eita and Sichi (2006). The coefficient of openness is positive and statistically significant, which indicates that trade liberalization measures will increase demand for tradeable, resulting to a deficit in current account and a depreciation of the REER. Similar result was obtained by Dumitrescu and Dedu (2009). Finally, money supply has a negative impact on the REER. Intuitively, increase in money supply will trigger an increase in the demand for non-tradeable goods, thereby increasing their prices, resulting to an appreciation of the REER in the long run.

\subsection{Equilibrium Real Effective Exchange Rate and Real Exchange Rate Misalignment}

Given the estimation of the long run parameters in equation (4), we proceed with the computation of the equilibrium real effective exchange rate (EREER). As alluded to earlier, to estimate the sustainable EREER, permanent values of the long run fundamentals in Equation 4, are obtained using Hodrick-Prescott filter methodology. The permanent values of the long run fundamentals are then multiplied by their corresponding coefficients in equation 4 to obtain the EREER. The result of the equilibrium real effective exchange rate is presented in Figure 2, which is juxtaposed with the actual REER. It is worthy to note that, Figure 2 shows a comparison between the estimated EREER and the actual REER. The result exhibits varying level of undervaluation and overvaluation. A close observation of Figure 2, also indicates that the REER was overvalued by 3.69 percent against the EREER between 1980-1985. Furthermore, the 
REER experienced episode of undervaluation of 1.8 percent between 1986 and 1997, but a reverse trend with an overvaluation of 0.97 percent between 1998 and 2004 .

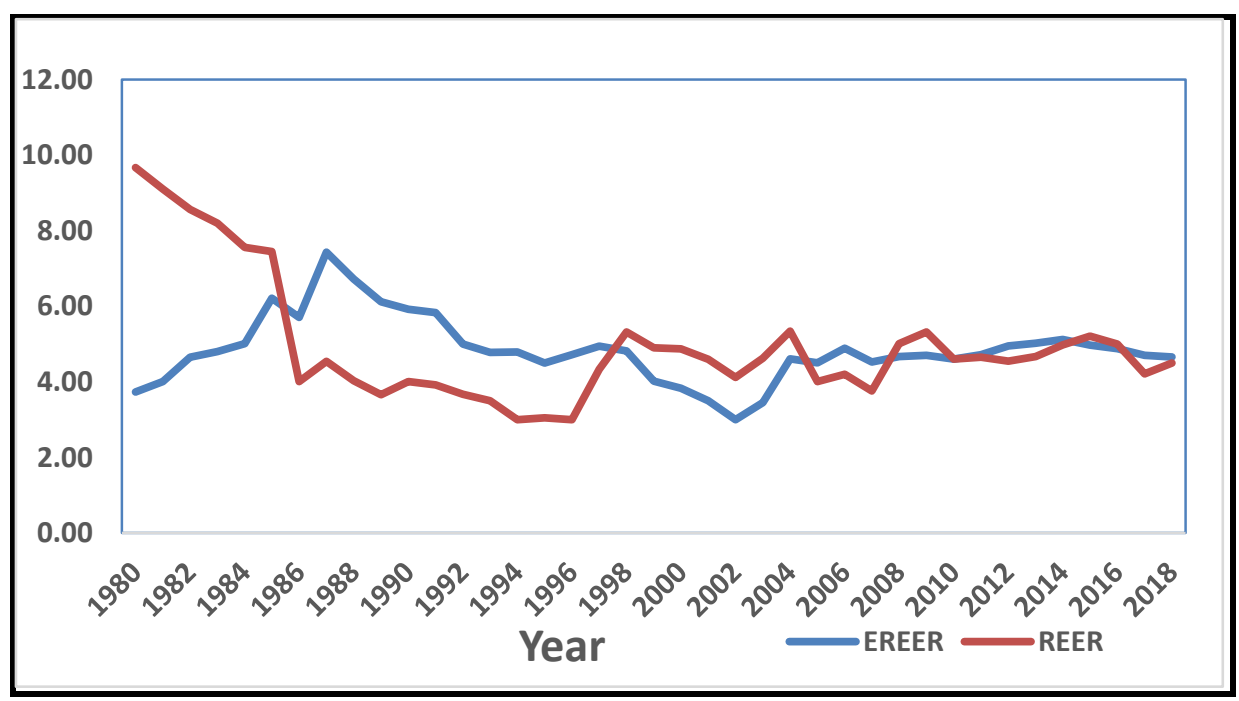

Figure 2. Equilibrium and Actual Real Exchange Rates (values in natural log)

Source: Author's computation

Following the computation of the EREER, we then proceed to determine the degree of real exchange rate misalignment, which is the sustained deviation of the actual REER from the EREER as presented in Equation 3. The result of the misalignment is presented in Figure 3. Critical analysis of Figure 3 shows that the REER of Sierra Leone was misaligned during the study period. The level of misalignment was more profound between 1980-85 and 1986-97. However, the level of misalignment was relatively lower between 2008-2018. Overall, the result confirmed that between 1980-2018, the REER was misaligned by 0.12 percent, which represent a moderate level of misalignment.

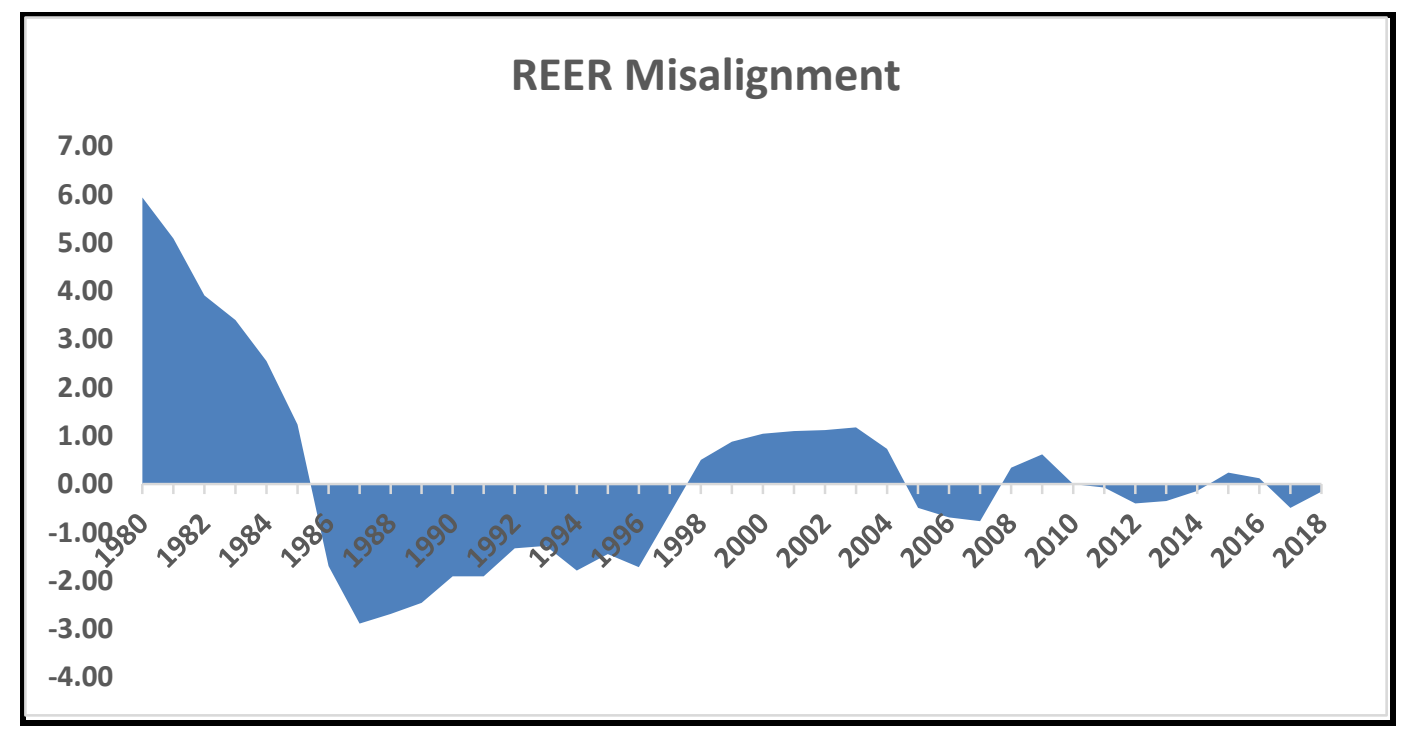

Figure 3. RER Misalignment

Source: Author's computation. Note: positive values represent overvaluation of the REER

\section{Conclusion}

The preoccupation of this paper was to estimate the equilibrium real effective exchange rate and the degree of exchange rate misalignment in Sierra Leone, with annual data from 1980 to 2018. The paper utilized the BEER methodology 
within the Johansen maximum likelihood framework. The stationarity test results revealed that all variables are I(1) series, whilst the cointegration test established one cointegrating vector as evident by both the Trace and Maximum Eigen Statistics. The normalized long run results showed that government expenditure, openness and money supply were the most significant determinants of the long run equilibrium. The result confirmed that openness and government expenditure had positive impact on the REER, which implies that both variables caused depreciation of the REER. Conversely, money supply had a negative impact, which denote an appreciation of the REER. Furthermore, the findings indicated that the REER experienced sustained deviation from the long run equilibrium real effective exchange rate during the study period, with episodes of overvaluation and undervaluation. Specifically, the REER witnessed profound overvaluation between 1980-1985 and 1998-2004, and an undervaluation between 1986-1997. The study also identified episodes of misalignment of the REER. Although the level of misalignment was more profound between 1980 and 2004, the result confirmed that between 1980-2018, the REER was misaligned by 0.12 percent, which represent a moderate level of misalignment.

The policy implication from the finding is that, the monetary authorities should ensure stability of the exchange rate and maintain price stability, through sterilization of capital flows as well as contain money growth within the statutory limit. Furthermore, to ensure stability of the exchange rate, there is need to increase domestic production and avoid over reliant on imports. As such, supply side policies that increase productivity are useful for the Sierra Leone economy. These include improvement in educational system, infrastructural development and provision of health facility, among others.

\section{References}

Abbes H. (2014). The Real Effective Exchange Rate Misalignment: Application of Behavioral Equilibrium Exchange Rate BEER to Algeria 1980- 2009. International Journal of Economics, Finance and Management Sciences, 2(5), 277-284. https://doi.org/10.11648/j.ijefm.20140205.12

Alberola, E., López, H., \& Servén, L. (2004). Tango with the Gringo: The Hard Peg and Real Misalignment in Argentina, World Bank Policy Research Working Paper 3322, June, World Bank, Washington DC. Retrieved from https://www.researchgate.net/publication/23549677

Baffes, J., Elbadawi, I., \& O’Connell, S. (1999). Single-Equation Estimation of the Equilibrium Real Exchange Rate in Exchange Rate Misalignment: Concepts and Measurement for Developing Countries, ed. by L. Hinkle and P. Montiel (New York: Oxford University Press). https://doi.org/10.1596/1813-9450-1800

Bahmani-Oskooee, M., \& Miteza, I. (2003). Are devaluations expansionary or contractionary? A survey article. Economic Issues Journal Articles, 8(2), 1-28.

Retrieved from http://www.economicissues.org.uk/Files/2003/203aBahmani.pdf

Daboh, L. (2010). Real Exchange Rate Misalignment in the West African Monetary Zone. The West African Journal of Monetary and Economic Integration, 10(2).

Dumitrescu, B. A, \& Dedu, V. (2009). The Estimation of the Equilibrium Real Exchange Rate for Romania. European Research Studies, XII(1). Retrieved from https://www.researchgate.net/publication/46542557

Eita, J. H., \& Sichei, M. M. (2006). Estimating the equilibrium real exchange rate for Namibia. University of Pretoria Working Paper, 2006-08, February. Retrieved March 10, 2021, from https://repository.up.ac.za

Elbadawi, I. A., \& Soto, R. (1994). Capital Flows and Long-Term Equilibrium Real Exchange Rates in Chile. The World Bank Policy Research Working Paper 1306, Washington DC.

Gachoki, C., Okeri, S., \& Korir, J. (2019). Determinants of equilibrium real exchange rate and it's misalignment in Kenya 2000-2016: an autoregressive distributed lag approach. International Journal of Economics, 4(1), 16-42.

Hodrick, R., \& Prescott, E. 1(997). Postwar U.S. Business Cycles: An Empirical Investigation,” Journal of Money, Credit and Banking, 29(February),1-16. https://doi.org/10.2307/2953682

Hyder, Z., \& Mahboob, A. (2006). Equilibrium Rear Effective Exchange Rate and Exchange Rate misalignment in Pakistan. SBP Research Bulletin, 2(1).

Ibrahim, W. (2014). Real Exchange Misalignment and Trade Flows in Nigeria (1960-2013). Journal of Academic Research in Economics, 6(3).

Iimi, A. (2006). Exchange Rate Misalignment: An Application of the Behavioral Equilibrium. IMF Working Paper, WP/06/140. https://doi.org/10.5089/9781451864007.001

Jayaraman, T. K., \& Choong, C. K. (2011). Equilibrium real exchange rate in Fiji: an empirical study. International Journal of. Monetary Economics and Finance, 4(3), 238-253. https://doi.org/10.1504/IJMEF.2011.040921 
Juthathip, J. (2009). Equilibrium Real Exchange Rate, Misalignment, and Export Performance in Developing Asia. Asian Development Bank, Working Papers 151 A. Retrieved from http://hdl.handle.net/11540/1798

Kiptui, M. C., \& Ndirangu, L. (2015). Determinants of Equilibrium Real Exchange Rate and its Misalignment in Kenya: A Behavioral Equilibrium Exchange Rate Approach. MPRA Paper No. 70542.

Lugaiyamu, L. (2015). Determinants of Exchange Rate in Tanzania. Uppsala University. Retrieved from http://hdl.handle.net/20.500.12018/2979

Moore, W., Skeete, R., \& Greenidge, K. (2004). Exchange Rate Misalignment in Selected Caribbean Countries. Central Bank of Barbados Working Paper. WP2003-2.pdf .

Petrevski, G. (2007). Equilibrium real exchange rate in Macedonia. International Journal of Monetary Economics and Finance, 1, 5-17. https://doi.org/10.1504/IJMEF.2007.016022

Zhang, X. (2002). Equilibrium and Misalignment: An Assessment of the RMB Exchange Rate from 1978 to 1999. Sandford University Working Paper No. 127.

\section{Copyrights}

Copyright for this article is retained by the author(s), with first publication rights granted to the journal.

This is an open-access article distributed under the terms and conditions of the Creative Commons Attribution license which permits unrestricted use, distribution, and reproduction in any medium, provided the original work is properly cited. 